\title{
Student's Science Literacy Skills with Problem Based Learning in Senior High School in Tanjungpinang
}

\section{Kemampuan Literasi Sains Siswa SMA Kota Tanjungpinang dengan Penerapan Problem Based Learning}

\author{
Nevrita $^{1)}$, Trisna Amelia ${ }^{1)}$, Desi Rahmatina ${ }^{2)}$ \\ 1) Program Studi Pendidikan Biologi, FKIP, Universitas Maritim Raja Ali Haji \\ ${ }^{2)}$ Program Studi Pendidikan Matematika, FKIP, Universitas Maritim Raja Ali Haji \\ Jalan Politeknik Senggarang Tanjungpinang, Kepulauan Riau, Indonesia \\ Email: nevrita@umrah.ac.id
}

\begin{abstract}
The average national exam score of biology subject in high school in Tanjungpinang tends to be the lowest among other subjects. It is assumed that the ability of student science literacy also tends to be weak. The role of teacher is very important to improve student's science literacy ability. Applying various learning strategies to create meaningful learning processes is one of the teacher's role. The strategy is Problem-based Learning (PBL) model. This research was conducted to determine science literacy ability of high school students in Tanjungpinang using PBL learning strategy. Research was conducted in SMA 4 and SMA 6 in Tanjungpinang with a sample 67 students. It is a quantitative approach with Quasi Experiment. PBL is free variable and science literacy skills as bound variable. Researcher uses tests, observation sheets and interviews as research instruments. Based on the results of this research can be concluded that implementation of $P B L$ gives significant difference for student's science literacy in tenth grade in SMA 4 and SMA 6.
\end{abstract}

Keywords: Student science literacy, Problem based learning, Senior high school

\section{PENDAHULUAN}

Kemampuan literasi sains siswa di Indonesia masih rendah berada di bawah standar, hal ini sesuai dengan penilaian yang dilakukan oleh PISA sebab Indonesia merupakan negara yang secara periodik ikut dalam penilaian PISA. Pengukuran PISA terakhir yaitu pada tahun 2015 menunjukkan bahwa Indonesia berada pada urutan 62 dari 70 negara (OECD, 2018: 5). Oleh sebab itu, sampai saat ini literasi sains di Indonesia merupakan permasalahan penting yang harus diusahakan cara mengatasinya.

Banyak faktor yang menyebabkan rendahnya literasi sains di Indonesia, diantaranya adalah masih lemahnya penerapan model pembelajaran yang digunakan dalam pendekatan saintifik. Model pembelajaran yang bisa diterapkan guru dalam pembelajaran diantaranya adalah model pembelajaran Problem Based Learning. Berdasarkan data prapenelitian diperoleh informasi bahwa guru Biologi SMA kota 
Tanjungpinang belum sepenuhnya memahami model pembelajaran PBL, bahkan sangat jarang menerapkan model pembelajaran PBL dalam proses pembelajaran. Penelitian ini dilakukan untuk mengetahui literasi sains siswa SMA Negeri di Kota Tanjungpinang dengan menerapkan model pembelajaran problem based learning

Literasi sains siswa harus terus ditingkatkan karena Literasi sains bersifat multidimensional apabila dipandang dari definisi literasi sains, bukan hanya pemahaman terhadap pengetahuan sains. Menurut Nofiana (2018: 25-26) individu yang "melek sains" adalah orang yang memanfatkan konsep ilmu sains, keterampilan proses, dan nilai dalam manfaatnya untuk membuat keputusan sehari- hari jika ia berinteraksi dengan lingkungannya, serta memahami interaksi antara sains, teknologi dan masyarakat, termasuk pada perkembangan aspek sosial dan ekonomi. Terdapat dua hal yang diperlukan diperhatikan dalam menilai tingkatan literasi sains siswa. Pertama, penilaian literasi sains siswa tidak ditujukan untuk membedakan seseorang literasi atau tidak. Kedua, pencapaian literasi sains merupakan proses yang kontinu dan terus meneruskan berkembang sepanjang hidup manusia. Jadi, penilaian literasi sains selama pembelajaran di sekolah hanya melihat adanya "benih-benih literasi" dalam diri siswa, bukan mengukur secara mutlak tingkat literasi sains dan teknologi siswa. (Zuriyani, 2011: 8)

Guru memiliki peranan penting dalam meningkatkan kemampuan literasi sains siswa, guru harus memiliki keterampilan dan pengalaman.dalam hal menentukan strategi mengajar yang tepat diantaranya dalam menentukan model pembelajaran yang lebih mengajak siswa agar memiliki kemampuan berpikir kritis, menganalisis, memecahkan masalah. Hal ini sejalan dengan pendapat Anggun, dkk (2017: 115) yang menyatakan model pembelajaran merupakan salah satu bagian penting yang harus dipertimbangkan dalam melaksanakan proses pembelajaran penerapan model pembelajaran yang tepat dapat meningkatkan literasi sains siswa. Kesemua kemampuan itu bisa diraih siswa dengan menggunakan salah satu model pada pendekatan saintifk yaitu model problem based learning $(P B L)$. Menurut Sudarman (2007: 69) PBL adalah suatu pendekatan yang menggunakan masalah dunia nyata sebagai suatu konteks bagi siswa untuk belajar tentang cara berpikir kritis dan keterampilan pemecahan masalah, serta untuk memperoleh pengetahuan yang esensial dari materi pelajaran, pembelajaran berbasis masalah dirancang untuk merangsang berpikir tingkat tinggi dalam situasi berorientasi pada masalah.Pada model PBL siswa diberikan permasalahan dikerjakan secara berkelompok dilibatkan dalam penyelidikan sehingga mampu membangun pemahaman tentang penyelidikan yang dilakukannya serta berusaha mencari solusi permasalahan melalui bahan bacaan, narasumber dan sumber lainnya. Menurut OECD (2016: 25) pada PISA 2015 dimensi literasi sains dikembangkan menjadi empat dimensi, aspek konteks, aspek konten, aspek kompetensi dan tambahannya yaitu aspek sikap siswa akan sains. 
Aspek konteks, PISA menilai pengetahuan sains relevan dengan kurikulum pendidikan sains di negara partisipan tanpa membatasi diri pada aspek-aspek umum kurikulum nasional tiap negara. Penilaian PISA dibingkai dalam situasi kehidupan umum yang lebih luas dan tidak terbatas pada kehidupan di sekolah saja. Butir-butir soal pada penilaian PISA berfokus pada situasi yang terkait pada diri individu, keluarga dan kelompok individu (personal), terkait pada komunitas (social), serta terkait pada kehidupan lintas negara (global).

Aspek konten, konten sains merujuk pada konsep-konsep kunci dari sains yang diperlukan untuk memahami fenomena alam dan perubahan yang dilakukan terhadap alam melalui aktivitas manusia. Dalam kaitan ini PISA tidak secara khusus membatasi cakupan konten sains hanya pada pengetahuan yang menjadi kurikulum sains sekolah, namun termasuk pula pengetahuan yang diperoleh melalui sumbersumber informasi lain yang tersedia. Kriteria pemilihan konten sains adalah sebagai berikut: 1) Relevan dengan situasi nyata, 2) merupakan pengetahuan penting sehingga penggunaannya berjangka panjang, dan 3) sesuai untuk tingkat perkembangan anak usia 15 tahun.

Aspek kompetensi/proses, PISA menetapkan tiga aspek dari komponen kompetensi/proses sains berikut dalam penilaian literasi sains, yakni mengidentifikasi pertanyaan ilmiah, menjelaskan fenomena secara ilmiah dan menggunakan bukti ilmiah. Proses kognitif yang terlibat dalam kompetensi sains antara lain penalaran induktif/deduktif, berfikir kritis dan terpadu, pengubahan representasi, mengkonstruksi eksplanasi berdasarkan data, berfikir dengan menggunakan model dan menggunakan matematika.

Aspek sikap untuk membantu siswa mendapatkan pengetahuan teknik dan sains, tujuan utama dari pendidikan sains adalah untuk membantu siswa mengembangkan minat siswa dalam sains dan mendukung penyelidikan ilmiah. Sikap-sikap akan sains berperan penting dalam keputusan siswa untuk mengembangkan pengetahuan sains lebih lanjut, mengejar karir dalam sains, dan menggunakan konsep dan metode ilmiah dalam kehidupan mereka. Dengan begitu, pandangan PISA akan kemampuan sains tidak hanya kecakapan dalam sains, juga bagaimana sifat mereka akan sains. Kemampuan sains seseorang di dalamnya memuat sikap-sikap tertentu, seperti kepercayaan, termotivasi, pemahaman diri, dan nilai-nilai.Wulandari dan Solihin (2016: 71) menyatakan pembelajaran yang mampu membangkitkan rasa ingin tahu siswa akan mendorong semangat siswa memecahkan masalah akan membangun keterampilan proses sains.Aktivitas pembelajaran mampu mendorong siswa untuk meningkatkan rasa ingin tahu yang tinggi sehingga memotivasi siswa untuk meningkatkan ketertarikannya terhadap issu-issu ilmiah yang memungkinkan untuk diselidiki melalui langkah-langkah metode ilmiah dan meningkatkan rasa tanggung jawab siswa terhadap lingkungan sekitarnya dengan menerapkan konsep sains yang telah dipelajari (Wulandari dan Sholihin, 2015: 440) 


\section{METODE PENELITIAN}

Metode penelitian yang digunakan adalah metode penelitian eksprimen dengan pendekatan kuantitatif. Desain penelitian yang digunakan dalam penelitian ini adalah penelitian quasi experimental. Penelitian ini menggunakan dua kelas tiap sekolah terdiri atas kelas kontrol dan kelas eksprimen yang dijadikan tempat penelitian. Selanjutnya siswa diberikan perlakuan yaitu pembelajaran sains dengan model problem based learning untuk kelas eksprimen dan model konvensional untuk kelas kontrol. Setelah perlakuan yang direncanakan sebanyak 2 kali pertemuan (6 x 45 menit) dilanjutkan dengan pemberian test akhir (postest) untuk melihat perbandingan kemampuan literasi sains siswa kelas X SMA Negeri Tanjungpinang. Dalam penelitian ini populasi adalah siswa kelas X SMA Negeri 4 Tanjungpinang, dan siswa kelas X SMA Negeri 6 yang kedua-dua sekolah berada di Tanjungpinang. Pengambilan sampel dalam penelitian ini dilakukan dengan teknik purposive random sampling. Instrumen pengumpulan data terdiri instrumen tes, lembar observasi dan pedoman wawancara. Teknik analisis data dengan melakukan beberapa uji antara lain uji normalitas, uji homogenitas dan uji statistik non parametrik.

\section{HASIL PENELITIAN DAN PEMBAHASAN}

a. Hasil

\section{Hasil Analisis Data Eksperimen Di SMA Negeri 4 Tanjungpinang}

Berikut merupakan hasil analisis uji normalitas nilai literasi sains di SMA Negeri 4 Tanjungpinang.

Tabel 1. Uji Normalitas Nilai Literasi Sains peserta didik SMA 4

\begin{tabular}{llllrrrr}
\hline & & \multicolumn{3}{c}{ Kolmogorov-Smirnov $^{\mathrm{a}}$} & \multicolumn{3}{c}{ Shapiro-Wilk } \\
\cline { 3 - 9 } & Kelompok & Statistic & df & Sig. & Statistic & df & Sig. \\
\hline SMA 4 & Eksperimen &, 116 & 32 &, $200^{*}$ &, 938 & 32 &, 067 \\
& Kontrol &, 214 & 35 &, 000 &, 912 & 35 &, 009 \\
\multicolumn{2}{l}{ a. Lilliefors Significance Correction } & & & & & & \\
\hline
\end{tabular}

Tabel 2. Uji Homogenitas Varians Kelas Eksperimen dan Kontrol SMA 4

\begin{tabular}{llrrrr}
\hline & \multicolumn{2}{c}{$\begin{array}{c}\text { Levene } \\
\text { Statistic }\end{array}$} & df1 & df2 & \multicolumn{1}{c}{ Sig. } \\
\hline SMA 4 & Based on Mean & 7,059 & 1 & 65 &, 010 \\
& Based on Median & 5,424 & 1 & 65 &, 023 \\
& Based on Median and & 5,424 & 1 & 42,873 &, 025 \\
& with adjusted df & & & & \\
& Based on trimmed mean & 6,537 & 1 & 65 &, 013 \\
\hline
\end{tabular}


Tabel 1 menunjukkan bahwa nilai signifikan Kolmogorov-Smirnov 0,200 > 0,05 dan nilai signifikan Shapiro- Wilk untuk kelas eksperimen 0,067>0,05 dan kelas kontrol 0,000<0,05 dan 0,009 $<0,05$ pada uji Kolmogorov-Smirnov dan Shapiro-Wilk, sehingga disimpulkan nilai literasi sains kelas eksperimen berdistribusi normal dan nilai literasi sains untuk kelas kontrol di SMA 4 tidak berdistribusi normal, maka uji parametrik (uji t ) tidak bisa digunakan untuk menguji perbedaan rata rata nilai literasi sains peserta didik di SMA 4 sehingga uji perbedaan rata rata nilai literasi sains dianalisis menggunakan statistika non parametrik.

Tabel 2 menunjukkan hasil uji homogenitas dengan menggunakan uji Levene's. Nilai Levene ditunjukkan pada baris Nilai Based on Mean yaitu 7,059 dengan nilai signifikan $0,010<0,05$, hal ini berarti tidak terdapat kesamaan varians antara kelas eksperimen dan kelas kontrol, dengan kata lain kedua kelas tersebut tidak homogen. Analisis dilanjutkan dengan menggunakan uji statistika non parametrik Mann-Whitney dikarenakan nilai literasi sains di SMA 4 tidak berdistribusi normal dan kedua kelas(eksperimen dan kelas kontrol) tidak homogen.

Tabel 3. Mean Ranks Nilai Literasi Sains SMA 4

\begin{tabular}{llrrr}
\hline & Kelompok & N & Mean Rank & Sum of Ranks \\
\hline SMA 4 & Eksperimen & 32 & 40,63 & 1300,00 \\
& Kontrol & 35 & 27,94 & 978,00 \\
& Total & 67 & & \\
\hline
\end{tabular}

Tabel 4. Uji Mann Whitney ${ }^{\mathrm{a}}$

\begin{tabular}{lr}
\hline & \multicolumn{1}{c}{ SMA 4 } \\
\hline Mann-Whitney U & 348,000 \\
Wilcoxon W & 978,000 \\
Z & $-2,668$ \\
Asymp. Sig. (2-tailed) &, 008 \\
Exact Sig. [2*(1-tailed & \\
Sig.)] & \\
\hline
\end{tabular}

a. Grouping Variable: Kelompok

b. Not corrected for ties.

Nilai Mean-Rank pada Tabel 3 menunjukkan peringkat rata rata nilai literasi sains masing masing kelompok, peringkat rata rata kelas eksperimen (Mean-Rank 40,63) lebih tinggi daripada peringkat rata-rata nilai literasi sains kelas kontrol (Mean-Rank 27,94). Untuk menguji apakah ada perbedaan signifikan peringkat rata rata nilai literasi sains antara kelas eksperimen dan kelas kontrol di SMA 4 digunakan uji Mann-Whitney seperti tampak pada tabel 4. Hasil uji MannWhitney 
pada Tabel 4 menunjukkan nilai signifikan $0,008<0,05$, hal ini menunjukkan bahwa ada perbedaan signifikan peringkat rata-rata nilai literasi sains peserta didik kelas $X$ IPA dengan penerapan PBL di SMA 4 Tanjungpinang.

\section{Hasil Analisis Data Eksperimen Di SMA Negeri 6 Tanjungpinang}

Berikut merupakan hasil analisis uji normalitas nilai literasi sains di SMA Negeri 6 Tanjungpinang.

Tabel 5. Uji Normalitas Nilai Literasi Sains peserta didik SMA 6

\begin{tabular}{llcccccc}
\hline & & \multicolumn{3}{c}{ Kolmogorov-Smirnov $^{\mathrm{a}}$} & \multicolumn{3}{c}{ Shapiro-Wilk } \\
\cline { 3 - 8 } & Kelompok & Statistic & df & Sig. & Statistic & df & Sig. \\
\hline SMA & Eksperimen &, 122 & 22 &, $200^{*}$ &, 966 & 22 &, 615 \\
6 & Kontrol &, 193 & 22 &, 033 &, 904 & 22 &, 035 \\
a. Lilliefors Significance Correction & & & & & \\
\hline
\end{tabular}

Tabel 6. Uji Homogenitas Varians Kelas Eksperimen dan Kontrol SMA 6

\begin{tabular}{|c|c|c|c|c|c|}
\hline & \multicolumn{5}{|c|}{ Levene } \\
\hline & & Statistic & df1 & df2 & Sig. \\
\hline \multirow[t]{4}{*}{ SMA 6} & Based on Mean & ,001 & 1 & 42 & ,981 \\
\hline & Based on Median & 067 & 1 & 42 & ,797 \\
\hline & $\begin{array}{l}\text { Based on Median and with } \\
\text { adjusted df }\end{array}$ & ,067 & 1 & 38,162 & ,798 \\
\hline & Based on trimmed mean & ,005 & 1 & 42 & ,944 \\
\hline
\end{tabular}

Dari Tabel 5 menunjukkan bahwa nilai signifikan Kolmogorov-Smirnov 0,200 > 0,05 dan nilai signifikan Shapiro-Wilk untuk kelas eksperimen 0,615>0,05 dan kelas kontrol 0,033<0,05 dan 0,035 $<0,05$ pada uji Kolmogorov-Smirnov dan Shapiro-Wilk sehingga disimpulkan nilai literasi sains kelas eksperimen berdistribusi normal dan nilai literasi sains untuk kelas kontrol di SMA 6 tidak berdistribusi normal, maka uji parametrik (uji t ) tidak bisa digunakan untuk menguji perbedaan rata rata nilai literasi sains peserta didik di SMA 6 sehingga uji perbedaan rata rata nilai literasi sains dianalisis menggunakan statistika non parametrik.

Tabel 6 menunjukkan hasil uji homogenitas dengan menggunakan uji Levene's. Nilai Levene ditunjukkan pada baris Nilai Based on Mean yaitu 0,001 dengan nilai signifikan $0,981>0,05$, hal ini berarti terdapat kesamaan varians antara kelas eksperimen dan kelas kontrol, dengan kata lain kedua kelas tersebut homogen. Analisis dilanjutkan dengan menggunakan uji statistika non parametrik Mann Whitney dikarenakan kelompok nilai literasi sains di SMA 6 tidak berdistribusi normal. 
Tabel 7. Mean Ranks Nilai Literasi Sains SMA 6

\begin{tabular}{llrrr}
\hline & Kelompok & N & Mean Rank & Sum of Ranks \\
\hline SMA 6 & Eksperimen & 22 & 33,14 & 729,00 \\
& Kontrol & 22 & 11,86 & 261,00 \\
& Total & 44 & & \\
\hline
\end{tabular}

Tabel 8. Uji Mann Whitney ${ }^{\mathrm{a}}$

\begin{tabular}{lr}
\hline & \multicolumn{1}{c}{ SMA 6 } \\
\hline Mann-Whitney U & 8,000 \\
Wilcoxon W & 261,000 \\
Z & $-5,498$ \\
Asymp. Sig. (2-tailed) &, 000 \\
Exact Sig. [2*(1-tailed & \\
Sig.)] & \\
\hline a. Grouping Variable: Kelompok & \\
b. Not corrected for ties.
\end{tabular}

Nilai Mean Rank pada Tabel 7 menunjukkan peringkat rata rata nilai literasi sains masing masing kelompok, peringkat rata rata kelas eksperimen (Mean Rank $33,14)$ lebih tinggi daripada peringkat rata-rata nilai literasi matematika kelas kontrol (Mean Rank 11,86). Untuk menguji apakah ada perbedaan signifikan peringkat rata rata nilai literasi sains antara kelas eksperimen dan kelas kontrol di SMA 6 digunakan uji Mann Whitney seperti tampak pada Tabel 8. Hasil uji Mann Whitney pada Tabel 8 menunjukkan nilai signifikan $0,000<0,05$, hal ini menunjukkan bahwa ada perbedaan signifikan peringkat rata rata nilai literasi sains peserta didik kelas $X$ IPA dengan penerapan PBL di SMA 6 Tanjungpinang.

\section{b. Pembahasan}

Hasil analisis data menunjukkan bahwa pada kedua sekolah yang menjadi tempat eksperimen (SMA N 4, dan SMA N 6 Tanjungpinang), diketahui bahwa terdapat perbedaan signifikan pada capaian literasi sains peserta didik melalui pembelajaran model Problem-based Learning $(P B L)$ dibandingkan pembelajaran model konvensional (Cooperative Learning). Capaian literasi sains peserta didik cenderung lebih tinggi secara signifikan saat dibelajarkan melalui model pembelajaran PBL, hasil ini secara konsisten terjadi pada kedua sekolah. Menurut Bahriah (2015: 16) bahwa hasil implementasi pembelajaran dengan menggunakan model pembelajaran berbasis masalah (Problem Based Learning) dapat meningkatkan literasi sains pada aspek konteks aplikasi dan proses sains. Tes capaian literasi sains yang dilakukan mengacu kepada tiga kompetensi ilmiah dalam 
literasi sains yaitu kemampuan mengidentifikasi isu-isu ilmiah, kemampuan menjelaskan fenomena secara ilmiah, dan kemampuan menggunakan bukti-bukti ilmiah. Melihat data yang diperoleh, dapat dipahami bahwa PBL menunjang terbentuknya ketiga kompetensi ilmiah dalam literasi sains.

PBL sebagai salah satu model pembelajaran yang sejalan dengan pelaksanaan pendekatan saintifik sebagaimana diamanatkan dalam kurikulum 2013, secara prinsip dapat memfasilitasi berkembangnya keterampilan pemecahan masalah (Standar proses K13) seharusnya sudah familiar di kalangan guru-guru sebagai praktisi pembelajaran. PBL dalam pelaksanaannya dilakukan secara berkelompok dalam 6-8 orang peserta didik yang kemudian diberikan suatu masalah untuk didiskusikan solusinya.

Materi virus pada eksperimen merupakan materi ajar biologi yang sangat relevan dengan prinsip pelaksanaan PBL, di mana dalam konten ini banyak sekali isu-isu yang dapat dijadikan konteks permasalahan dalam kehidupan nyata sehingga memungkinkan peserta didik mengembangkan kemampuan pemecahan masalah. Isuisu nyata dalam lingkup nasional dan global mengenai penyebaran virus yang menyebabkan penyakit tertentu, menjadi orientasi arah diskusi peserta didik sekaligus menjadi masalah yang harus didiskusikan solusinya. Langkah-langkah PBL yang diterapkan meliputi: orientasi pada masalah, pengorganisasian kelompok belajar, melakukan penyelidikan, menyajikan hasil karya, dan analisis/ evaluasi proses penyelesaian masalah. Peserta didik melalui LKS diarahkan untuk menyelesaikan permasalahan yang diajukan guru yang berbeda setiap kelompoknya serta diminta untuk menghasilkan karya sebagai hasil pemikiran menyelesaikan masalah yang ada (dalam bentuk poster sederhana).

Pada membelajaran di sekolah Grant dan Dianne dalam Babalola (2013) menyarankan bahwa literasi sains dapat ditingkatkan dengan melakukan beberapa strategi, di antaranya; (1) guru mengidentifikasi topic yang menarik; (2) mendorong peserta didik untuk membaca hasil penelitian; (3) mengajari peserta didik untuk membaca sebagaimana ilmuwan; serta (4) membimbing peserta didik untuk menganalisis data. Dalam pembelajaran bermodel PBL yang dilakukan, keempat strategi yang disarankan terintegrasi ke dalam langkah-langkah PBL. Di sini dapat dipahami mengapa PBL dapat meningkatkan capaian literasi sains peserta didik di kelas eksperimen. Menurut Irnaningtyas, dkk (2016: 7) penerapan model PBL juga meningkatkan literasi sains peserta didik, karena pada dasarnya PBL merupakan model pembelajaran berbasis konstruktivis sehingga membantu peserta didik dalam pematangan konsep yang dimiliki. Hasil yang sama ditunjukkan oleh penelitian di pendidikan tinggi yang dilakukan oleh Pujiastutik (2018: 65) bahwa implementasi model pembelajaran Problem Based Learning (PBL) meningkatkan kemampuan literasi sains secara signifikan. PBL juga diketahui mendorong peserta didik untuk terlibat dalam pembelajara aktif dan mendalam, tidak hanya memahami konten ilmu, 
namun juga menguasai konteks yang terkait dengan permasalahan sehari-hari (Wood, 2004: 23)

Mencermati hasil keseluruhan data penelitian, dapat disimpulkan bahwa implementasi model PBL berpengaruh positif bagi capaian literasi sains peserta didik. Guru hendaknya lebih sering menerapkan model PBL dalam pembelajaran biologi apalagi konten dalam mata pelajaran biologi sangat dekat dengan kehidupan siswa.

\section{PENUTUP}

Penerapan PBL memberikan perbedaan signifikan terhadap literasi sains peserta didik kelas X di SMA 4, dan 6 Tanjungpinang. Penerapan PBL menunjang terbentuknya tiga kompetensi ilmiah dalam literasi sains, yaitu kemampuan mengidentifikasi isu-isu ilmiah, kemampuan menjelaskan fenomena secara ilmiah, dan kemampuan menggunakan bukti-bukti ilmiah.

\section{REFERENSI}

Anggun Sari DV, Rusilowati A dan Nuswowati M 2017 Pengaruh Pembelajaran Berbasis Proyek terhadap Kemampuan Literasi Sains Siswa. PSEJ Volume 2 Nomor 2, 114-1

Babalola J. Ogunkola. 2013. Scientific Literacy: Conceptual Overview, Importance and Strategies for Improvement Journal of Educational and Social Research Vol. 3 (1) January 2013.

Bariah, E.S. 2015. Peningkatan Literasi Sains Calon Guru Kimia pada Aspek Konteks Aplikasi dan Proses Sains.Jurnal: Edusains, Volume 7, Nomor 1, Tahun 2015, 11-17.

Imaningtyas. C D, dkk. 2016. Penerapan E-Module Berbasis Problem Based Learning untuk Meningkatkan Literasi Sains dan Mengurangi Miskonsepsi pada Materi Ekologi Siswa Kelas X MIA 6 SMAN 1 Karanganom Tahun Pelajaran 2014/2015. Jurnal: Bioedukasi, Volume 9, Nomor 1, Februari 2016, 4-10.

Nofiana M. dan Julianto T (2018). Upaya Peningkatan Literasi Sains Siswa Melalui Pembelajaran Berbasis Keunggulan Lokal. Biosfer : Jurnal Tadris Biologi, 2435.

OECD 2016. PISA 2015 Assessment and Anaytical Framework: Science, Reading, Mathematic, and Financial Literacy. Paris: OECD Publishing. 
OECD 2018 PISA 2015 Results in Focus.https://www.oecd.org/pisa/pisa-2015results-in-focus.pdf. Diakses 30 september 2019.

Pujiastutuik H 2018. Peningkatan Sikap Literasi Sains Peserta Didik melalui Model Pembelajaran Problem Based Learning Pada Mata Kuliah Parasitologi. Jurnal Biogenesis Vol. 14(2): $61-66$.

Sudarman 2007 Problem Based Learning: Suatu Model Pembelajaran untuk Mengembangkan dan Meningkatkan Kemampuan Memecahkan Masalah. Jurnal Pendidikan Inovatif Volume 2, Nomor 2, Maret 2007, 68-73.

Wood, Edward J. 2004Problem-based learning Acta Biochimica Polonicha. Vol. 51 No. 2.

Wulandari, N \& Sholihin, H. (2015). Penerapan Model PBL pada Pembelajaran IPA Terpadu untuk Meningkatkan Aspek Sikap Literasi Sains Siswa SMP. Prosiding Simposium Nasional Inovasi dan Pembelajaran Sains 2015 (SNIPS 2015), 8-9 Juni 2015. 437-440.

Wulandari, N \& Sholihin, H. (2016). Anaalisis Kemampuan Literasi Sains pada Aspek Pengetahuan dan Kompetensi Sains Siswa SMP pada Materi Kalor. Jurnal: Edusains Volume 8, Nomor 1, Tahun 2016, 66-73.

Zuriyani, E. 2011. Literasi Sains dan Pendidikan. http://sumsel.kemenag. go.id, diakses 1 Oktober 2019. 